\title{
The Seaside Resort as Entrapment and Escape in British Cinema
}

Zsolt Győri

https://doi.org/10.30608/HJEAS/2021/27/1/6

\section{ABSTRACT}

British cinema has portrayed seaside resorts throughout its history with much dedication. Films featured both residents and visitors, the providers and the consumers of the seaside experience decade after decade by focusing on the synergies between space and identity. This article explores Brighton Rock (John Boulting, 1948), The Entertainer (Tony Richardson, 1960), The Birthday Party (William Friedkin, 1968), Quadrophenia (Franc Roddam, 1979), Bhaji on the Beach (Gurinder Chadha, 1993), and Last Resort (Pawel Pawlikowski, 2000) as representative examples of how the motifs of escape and entrapment - as manifested in the pursuit of various imaginations, ideals, rites of passage and identity quests — changed through the decades that also saw a gradual decline in the popularity of seaside resorts. The fading reputation and eroding image of resorts is analyzed parallel with the identity crises of characters entrapped in subcultural, diasporic, and migrant environments. (ZsGy)

KEYWORDs: British cinema, seaside resorts, entrapment, escape, liminality, rites of passage

In Michael Winterbottom's recent comedy drama Greed (2019), a seaside villa on the Greek island of Mykonos serves as the location of a lavish Roman-themed birthday party. A minisized Colosseum is filled with heaps of self-centered guests who are about to enjoy a night of profuse, yet utterly tasteless entertainment, including a glamorous gladiator show and 
spectacular fireworks. All of this is arranged for a member of the elite club of billionaires, Sir Richard McCreadie, a high street fashion tycoon, who has recently come to the center of media attention due to a tax evasion scandal. As such, the festivities offer a release from daily stress and also a deceptive assurance for the ruthless neoliberal businessman that things are going well. With the spectacular carnival, McCreadie aims to conquer his worst nightmare of being excluded from the global celebrity elite and having become dead in their eyes. Simply put, the space of the lavish seaside compound becomes the externalization of a distressed mind and a self-deceptive attempt to escape the public purging of his corporate image.

This tale of self-importance and immorality, eventually tragic since McCreadie is devoured by a ferocious lion used as an accessory for the festivities, is the latest addition to British cinema's take on the seaside resort, a socioculturally well-defined space of ephemeral communal experience. Not unlike McCreadie, masses have flooded these places with the clear intent to leave the drudgeries of life behind. It is a site to fulfill the holiday dream defined by Gary Cross as a "release from routine, a radical change from accustomed space, time, and activity" (42). From among the many factors associated with the seaside in popular imagination, escape and recreation stand out, their predominance having been established in the past three centuries.

While the aristocracy from the late eighteenth century and their fashionable practice of taking curative vacations (balneotherapy) had a seminal role in putting the seaside on the map of recreational places, it was the nineteenth century urban middle-class and profit seeking financial investors, who accounted for the rapid expansion of seaside resorts, also popularized in literary accounts and travel guides. The democratization of leisure and the emergence of the mass tourism industry, accompanied by a fast build-up of the necessary travel and architectural infrastructure to host visitors in the twentieth century, meant a new boost for seaside recreation, the main benefactors of which were day tripper working class families. 
The gradual evolution of seaside resorts - from highbrow through middlebrow to lowbrowpresents a transforming image shaped by social imaginations that associate different meanings, experiences, and fantasies with this space. Notwithstanding, escape remained the dominant function of the resort; in fact, its whole history was shaped by factors that either limited or supported this function.

The social construction of the seaside meant that its image was made and remade by both class-specific rituals and the rich interaction of classes. In the last century, group interactions between the middle class and the working class in the form of cultural exchanges and shared spatial practices (for example, strolling, bathing, dining) strengthened qualities of seaside resorts that reach across class. Nevertheless, somewhat neutralizing their many potential benefits, the transgressions and subversions characteristic of liminal zones between classes also rigidified stereotypical perceptions. This was inevitable, since with the expansion of mass society, the seaside recreation industry as a whole and businesses at resorts in particular, had to satisfy the cultural needs of all visitors. The market approach to recreation naturally led to frictions, as certain forms of working-class self-enjoyment (necessary to experience the escape to the fullest) were met with annoyance on the part of the middleclasses. Differences in the cultural practice of seaside recreation prompted further changes in the image of these tourist destinations and have led to a steady decline of their popularity since the second half of the twentieth century. Besides seeking higher quality services and more authentic experiences, middle-class holidaymakers have always articulated a certain aversion towards what Garry Cross and John K Walton describe as the "crowded, noisy, vulgar, unbuttoned, uninhibited enjoyment . . the suspension of dignity and inhibitions, the reign of gluttony, extravagance, and licentiousness" (6). Cultural differences and opposing notions regarding the nature and authenticity of escape have been likewise emphasized by relevant scholarship (John Urry 1990, Urry 1997, Morgan and Prichard 1999). 
Rob Shield's historical inquiry into the transformation of Brighton acknowledges this shift from a curative center offering medical sea-bathing into the British seaside capital, a fashionable leisure site first for the affluent middle class, then for industrial laborers as well. In Shield's words: "The take-over of the aristocratic Brighton Season with the increasing presence of the middle class of 'wealthy citizens' was followed by a boom in popular seaside patronage with the steady growth of the laboring man's family holiday between 1841 and 1930" (85). With pleasure becoming a marketable commodity and pursued no longer by the selected few, the clear distinction of the "high" and the "low" in Victorian morality was hard to maintain. Privacy valued high amongst the middle and higher classes was compromised by gleeful anonymity or, as Shield claims, the "carnivalesque loss of identity" (97) in the liminal spaces of seaside resorts.

Both moral regulation (and its transgression) and the cult of privacy confronted by bacchic communality are central notions of the cultural logic that underpinned the social construction of the space of seaside resorts. All this is richly reflected in cinema as Matthew Kerry demonstrates in The Holiday and British Film, a comprehensive historical overview of filmic representations of British seaside resorts. Yet, a close analysis of popular perceptions of seaside holidays and cinema-going in the first half of the twentieth century draws attention to escapism as a common motif: "[t]he filmic holiday journey offers a sense of escape, and a temporary release from the stress of everyday life" (24). In the expression "filmic holiday journey" the escapist experience of carefree frivolity and glittering amusements merge. Studying Mass Observation reports about Blackpool in the 1930s, Lara Feigel finds that this form of escapism was a joyful acceptance of mass identity, collective experience and behaviour: "The masses at Blackpool were rejecting the potential offered by their weekly holiday to be individuals . . . surrendering their power to make personal decisions by blindly following the crowd" (26). In this assertion, the power embodied by community not only 
dwarfs the individual, but also assigns a sense of being dead to those who fail to partake in communal social rites. For Mass Observers the experience of escaping the monotony of life by entering the utopian carnival remains ephemeral and erodes one's individuality: it leads to a self-deceptive repression of an otherwise entrapped identity, be that socioeconomic, existential, or psychological entrapment. In other words, it is the wilful suspension of the fearsome knowledge of being dead for the utopian ideal of being alive.

If the seaside resort was the spatial symbol of only the eternal carnival, its representations would be unanimously liberating. This, however, is not the case, at least not in the films I analyze here, titles which seem to identify the more alarmist voices of social researchers and commentators from previous decades. I focus on cinematic representations of the holiday escape as a cultural practice uniquely associated with the seaside. In addition, I explore how the real locations presented in the films spatialize characters' anxieties associated with entrapment and the self-delusions behind escape. In my readings of Brighton Rock (John Boulting, 1948), The Entertainer (Tony Richardson, 1960), The Birthday Party (William Friedkin, 1968), Quadrophenia (Franc Roddam, 1979), Bhaji on the Beach (Gurinder Chadha, 1993), and Last Resort (Pawel Pawlikowski, 2000), I concentrate on the synergies between space and character, the pursuit of various imaginations, ideals, rites of passage, and identity quests, through which protagonists connect with seaside resorts. I am chiefly interested in films that portray this connection relying on the motifs of entrapment and escape, narratives in which characters are either entrapped by resort towns and their own misguided attempts of self-realization or hope to find release from anxieties and the feeling of being lost in the world through the seaside escape. I do not aim to offer a clear typology of cinematic representations, only to introduce the dynamics and the framework within which characters reflect upon space and vice versa. 


\section{Brighton Rock: the Gangster as Individual}

Based on Graham Greene's 1938 novel of the same title, Brighton Rock was released a decade later as a prominent example of the post-war gangster thriller. The actual turf wars between racecourse gangs, already a thing of the past when Greene originally wrote the story, still fascinated people and so did the adventurousness and frivolity sought by many daytrippers. The cinematic portrayal of teenage crime boss Pinkie follows on the footsteps of the Hays-code gangster hero, ${ }^{1}$ whom Robert Warshow describes as "the man of the city . . not the real city, but that dangerous and sad city of the imagination which is so much more important, which is the modern world" (131). Brighton and Pinkie are symbiotic and, unlike other members of his gang, he has no intention of moving on. Not that he likes the crowded pier or the tourists who enjoy its many attractions; in fact, he considers them as a nuisanceand yet he needs them. Not only as indirect sources of income, since he collects protection money from owners of small businesses on the pier and the seafront, but also as symbols of the weak and effeminate herd in contrast with his masculine individuality. The protection racket would only make him a criminal, while the gangster, as Warshow asserts, is born from the belief that "one must emerge from the crowd or else one is nothing" (132, emphasis added). This compulsion to emerge as an individual results in the suppression of affections of any sort, in a hegemonic masculinity coupled with hyperrational subjectivity and toxic individuality, governed by a superego that must negate all instinct of sociability.

In this light, the egotism and sense of superiority of the gangster in Brighton Rock does not derive from the patriarchal power of the mob boss. Due to his young age, Pinky's masculinity is somewhat ambiguous and needs to be repeatedly asserted through verbal cruelty, for instance, in his conversations with Rose, or through the coldblooded murder of Fred Hale and Spicer. He needs to be tough like the mobsters of the cinematic city, the men who depend on nobody but on whom everyone depends. As such, Pinky's strife for 
masculinity is tied up with toxic individuality, and will form the obverse of the attitude of Brighton's tourism-minded service personnel, always charming and welcoming, Rosie being its prime example. He is engulfed by a cold, sadistic compulsion to resist emotions as part of his aspirations to become a gangster. What constitutes his real entrapment is the blind pursuit of the toxic ideal according to which, in order to grow up and become an autonomous individual, one must take the path of gangsters. Although Greene describes Rosie's presence for Pinky as redemptive: "he had a sense that somewhere, like a beggar outside a shuttered house, tenderness stirred, but he was bound in a habit of hate" (Greene 289), the boy obviously rejects her on fears of being feminized if showing compassion. Pinky is hard all the way, like a Brighton Rock, best captured in the film by his stiff posture and indifferent face, which resemble recurring images of the sea as an unbending destructive power, a turbulent and steely hell.

Pinky's tragic individuality stands in a less stark contrast with the cultural image of Brighton in Rowan Joffe's 2010 adaptation of Brighton Rock. This film revels in nostalgia for coastal resorts in general, and Brighton in particular-the gulls, ice-cream trucks, puppet shows for children, fish and chips, deck-chairs, rowing on the seafront, kids flying paper kites, the Place Pier, the Metropole Hotel, and the Royal Pavilion - to emphasize the rich cultural heritage of the place. Pinky's individuality embedded in explosive violence is contrasted with these visual clichés in an especially graphic manner during the butchery of Fred Hale and the attempted murder of Spicer, two scenes that juxtapose images of the Brighton of seaside tourism and the ways of the underworld. In a clever move, the story is set in the 1960s, during the so-called "seaside riots," when mods and rockers brought havoc to Brighton. Showing Pinky riding a scooter, wearing the stylish attire of male mods might even suggest that he is less a gangster than a member of a classless subculture. The introduction of subcultural violence into the picture somewhat tames his immoral pursuit of individuality; nevertheless 
the ending unveils the wolf beneath the sheep's skin and depicts the protagonist no less a psychopath than the 1948 version did. The spatialization of a disturbed psyche follows alternate strategies in the two films: Boulting likens Pinky to the stormy sea, the natural element of Brighton, while for Joffe, Brighton as a cultural, social, and communal space is contrasted with the openly graphic depictions of Pinky's violence. Yet, both adaptations highlight how the character's compulsive pursuit for individuality becomes a menace that upsets the seaside communal idyll by projecting onto the space of the resort the restless violence of the neurotic and masculine city.

\section{The Entertainer: the Last of the Music Hall}

John Osborn's play, The Entertainer, was both stage-produced and adapted to the big screen by Tony Richardson, one of the virtuosi of British directors and a pioneer of social realist cinema. Unlike the bulk of British new wave films, The Entertainer-within the framework of a gritty family melodrama-portrays the demise of the music hall, a key cultural institution of the working class. By the early twentieth century, and with an evergrowing stake in consumer culture, the music hall became a standard attraction of popular resorts all over the country. As such, this much-demanded form of theatrical entertainment stood as the "great leveller," and appealed to the tastes of people coming from different walks of life and parts of the county. In the foreword to the published version of his play, Osborne himself described the music hall as a national institution and its demise a loss for the whole country: "The music hall is dying, and with it, a significant part of England. Some of the heart of England has gone; something that once belonged to everyone, for this was truly a folk art" (Osborne 7). One piece of the heart lost was the seaside resort, which in its rise, glory, and decline was intimately linked with the development of popular culture. Had Osborne changed the words "music hall" and "folk art" in the above quote for "seaside resort" and "popular 
attraction," he would have made an equally legitimate claim. The Entertainer is an elegy for the music hall but also for Morecombe, the actual setting of the film, which, as Richardson asserts, was "a failed popular resort with failed piers and crumbling theatres, the second-class sister to the livelier, more raucous, still popular Blackpool” (Richardson 138).

The stage play and the film capture the human drama of the slow demise of the music hall and the holiday town through the existential and artistic crises of protagonist Archie Rice, whose star image at the beginning of the film is loudly celebrated. The exterior of the venue he runs is decorated with a giant painted billboard with his face and the words "The one and only Archie Rice," posters advertise him as a radio and TV comic, and photos feature him in the company of young, loosely dressed female dancers. He poses as the epitome of quality entertainment and his star-image, emphasizing masculine qualities, is intended to justify his unique talent. Archie is a jester, a singer, a stand-up comedian, a master of ceremonies: indeed, a man for all seasons. His celebrity status is very different from that of his father's, Billy Rice's, the retired music hall legend, whom we hear sing only once in the film for and with an elderly audience in a pub. As opposed to this intimate communality, Archie hosts the Miss Great Britain beauty contest, a novelty entertainment intended for a passive crowd and supervised by the figure of the eccentric showman. He is an entertainer with a microphone, the appearance of which ultimately changed the nature of the music hall and allowed for larger venues and audiences. But as Billy Rice's sarcastic remark suggests—-I'll see those five-minute microphone wonders out any day,"- the microphone only brought predominantly business-type star entertainers with inferior talents, Archie being their prime example.

The image of the successful entertainer in the opening shots proves to be a deceptive business trick, a narcissistic fantasy. The Great Archie is not at all great, but a penniless vaudevillian whose theme song "Why should I care" is "the anthem of resignation and futility" (Tibbets 73) performed in an increasingly hollow and pitiful manner. Whereas the 
business model of the music hall might be crumbling under external factors, the protagonist's artistic achievement is disintegrating from within: as a single hit star, Archie is trapped within a stalled career. While the story might suggest that Archie is a burnt-out entertainer, someone who has lost his artistic aura and can no longer fulfill the daily task of impressing an evershrinking audience, in fact, he is a person who comes to admit he has worn a deceitful mask all through his career. In a dramatic confession to his daughter, Jean, he speaks of being empty at the core, long dead:

[I]f you learn it properly, you get yourself a technique. And smile, darn you, smile and look the friendliest, jolliest thing in the world. But you'll be just dead and used up. Just like everybody else. See this face? This face can split open with warmth and humanity. It can sing. Tell the worst, unfunniest stories in the world to a great mob of dead, drab jerks. And it doesn't matter. It doesn't matter because look. Look at my eyes. I'm dead behind these eyes. I'm dead. Just like the whole damn shoddy lot out there. $(01: 18: 24-01: 19: 19)$

Here Archie describes the inertia that the heightened affective state of performing in front of large crowds might temporarily suppress, but never eliminate. His escape from the real world onto the stage is futile, as he is unable to deliver the carnivalesque experience that comes so naturally to his father. Archie is used up and worn out in the eventually futile attempts to cover up apathy. His decision not to move to Canada and into the family hotel business supports the suspicion that he is not simply burned out or in dire need for a change of scene. For Archie, leaving Morecombe behind is not a possibility but an impossibility, which is a key aspect of his identity crisis-you can retire from the entertainment industry, but how do you retire from being a failed person? 


\section{The Birthday Party: The Seaside Resort Abstracted}

Completed in the same year as Osborne's play, Harold Pinter's The Birthday Party was made into a film by William Friedkin a decade later. Unlike The Entertainer, which truly liberates action from the confines of theatrical space and uses popular Moracombe sites - the Alhambra Theatre, the West End Pier, and Morecambe Winter Gardens-as shooting locations, Friedkin's film could have been filmed in any British town or, indeed, any living room in the Western hemisphere. The realism and functionality of the setting nevertheless receives symbolic significance as the story covers ground. Commenting on the settings in Pinter's plays, Ruby Cohn asserts that "these rooms look naturalistic, meaning no more than the eye can contain. But by the end of each play, they become sealed containers, virtual coffins" (56). Yet Pinter clearly specifies the setting as "the living room of a house in a seaside town" (9, emphasis added), in fact, a boarding house, so we might presume that the story takes place in a seaside resort town. The film is more specific, as the initial shot shows a man, most likely Petey, putting out deck chairs at a seaside terrace, and as the opening credits sequence ends with a long-shot of seafront with a candelabra lamppost in the foreground, and dim contours of a pier in the background. The empty beach, the deserted promenade, and the street lights going out suggest the arrival of the off-season. Especially at these times, a paying guest is a prized possession for the older couple who run the boarding house. Stanley is a fugitive from the city, bringing a bit of innocent romance to the woman without disturbing the man of the house, who hardly ever looks up from behind his newspaper. If Stanley is the ideal guest, McCann and Goldberg are annoying city dwellers with their domineering and superior attitudes. The two men embody what Stanley is trying to escape from-a dehumanizing System founded on "the sacred clichés of family, class, prudence, proportion" (Cohn 63). 
While most scholars address issues related to the theatricality of The Birthday Party (Hollis 1970), the psychopathology of characters (Kirby 1978), and its allegorical portrayal of a rite of passage (Burkman 1971), or apply socio-psychological frameworks to understand it (Cohn 1962, Lesser 1972), they all agree that its main literary motifs are failed escape and entrapment as a human condition. Friedkin portrays the (im)possibility of retreat from a menacing world that lies beyond the seaside resort as a timeless human drama. On this stage, all who seek to feel alive and liberated are Stanleys, who self-deceptively suppress their McCanns and Goldbergs. Friedkin clearly understands the intended ambiguities of the play, including the lack of information, on the one hand, about the protagonist's line of work, past life, and nature of his nervous breakdown, and, on the other hand, about the institutional affiliation and motives of the perpetrators. In addition, the director also relies on the social spatialization of the seaside resort, a space constructed through the competing forces of release and capture. The former promise autonomy, liberation, and change, qualities deemed as naïve and illusionary by the forces of capture, of domination, and of hegemony. This is most palpable in the way the (masculine) urban characters easily exploit and manipulate Lulu and Meg, both of whom embody the (feminine) seaside. Aiming for balance, The Birthday Party also acknowledges the perspective of the carnivalesque self and the forces of release and vitality. From this angle, the city is always already somewhat dead with its dwellers engulfed by monotony and neuroses. The forces of capture lie behind the empty, repetitive rituals of city-dwellers as seen in McCann's shredding of a sheet of paper-a repetitive act without cause, reason, or use.

In my understanding Friedkin (not unlike Pinter) portrays the social space of a seaside resort past its prime, in a phase of decline, when it no longer supports progression and liberation, only retrogression that is brought to surface through the narrative formula of the reversed rite of passage. In The Birthday Party, there is something childlike in the protagonist 
already at the beginning of the story. The landlady, Meg, according to Simon O. Lesser, shows "libidinized though mainly maternal love for Stanley" (38) that infantilizes the hero even before the arrival of the assertive patriarchal figures of Goldberg and McCann. Also, he remains neutral towards the romantic advances of Lulu, and behaves as someone inexperienced in the field of sexuality. What on the surface seems a carefree existence terminates once the two men appear and constantly humiliate Stanley as if he was a child. The actual birthday party is a liminal initiation ritual, which Colin Thomas regards as "a treacherous transition into male adulthood" with "masculinity as organization." In disagreement with this assertion, I claim that it is a reversed rite of passage, a ritual of infantilization.

During the birthday party, behind the façade of a carnivalesque communal feast, there is humiliation and verbal, even physical, harassment. For example, as the company plays a game of blind man's bluff, McCann breaks Stanley's glasses and the toy-drum he received as a present. The toy-drum, every little boy's dream present, is another sign of depriving Stanley of masculine adulthood. The sitting room, as the space of seemingly careless enjoyment, becomes increasingly claustrophobic, and ultimately, after the sudden blackout, a dark cell of aggression and catatonia. Instead of the liberating loss of identity and the ecstatic experience of feeling alive, the party is but a ritual of depriving Stanley from the agency he believes to have possessed. By the third act, he regresses into a baby, making sounds without meaning. Viewers are overwhelmed by a sense of him being dead, by his utter vulnerability and irreversible entrapment, a hard-to-stomach feeling underlined by images of his self-imposed guardians assisting him to their car and driving him off towards an unspecified fate. Despite its unwillingness to visually document the everyday reality of the seaside resort, I regard The Birthday Party as a significant representation of the seaside resort since it illuminates how this unique British institution is framed by the socially-driven forces of release and capture. 


\section{Quadrophenia: The Brighton of the Mods}

Brighton's libertarian reputation was one cause behind its marred image. This was never more apparent than during the violent conflicts between the Rocker and the Mod subcultures in the 1960s. Well before Franc Roddam's Quadrophenia (1978), plenty of Modthemed screen productions featured the Southern-English seaside resort, including Linda (1960, Don Sharp), Be My Guest (1965, Lance Comfort), and Made (1972, John Mackenzie). Yet, never before had Mod as a complex style of self-expression-with its emphasis on neat and tidy appearance; weekend outings on scooters uniquely decorated with peacock fans of wing mirrors; regular attendance of clubs, pubs and record shops; the consumption of amphetamines; and the love of the rock band The Who-so openly been addressed.

Affluence in the wake of the strong economic performance in the 1950s, a pull factor of upward mobility, hand-in-hand with liberalizing public morals and the glamorous world of the Swinging Sixties, contributed to the fact that it was not the bitter experience of socioeconomic and cultural deprivation the Mod subculture arose from. Still, despite the relative financial security, job appreciation was low for members of this subculture and primarily served as a means to seek collective forms of pleasure. As Dick Hebdige noted, "beneath the world's contempt, there were different priorities: work was insignificant, irrelevant; vanity and arrogance were permissible, even desirable qualities, and a more furtive and ambiguous sense of masculinity could be seen to operate" (Hebdige 54). "Real work," that is, the meaningful activity of perfecting one's image and cementing one's position within this alternative communality, came at the weekends and during bank holidays, as in the case of Jimmy, the protagonist of Quadrophenia. For Mods, psychical mobility was a crucial component of their subcultural image and also the means to escape the monotony of a working life and quarrelsome relationships with parents. However, with the expanding 
popular appeal and mass media inducing the visibility of the subculture, chasing the image became more important than resistance, even if this meant a turn towards deviance and violence. $^{2}$

The aforementioned appeal to mobility and violence in Roddam's film culminates in the lads' escape into fantasies of working class masculinity. While London is presented as the cultural hive of the Mods and the site of occasional conflicts with Rockers, their rivalry peaks in Brighton. Chance encounters on the streets of the capital might result in occasional exchanges of fists between members of the two groups; nevertheless it is in Brighton that the parties engage in a full-blown conflict, which is less personal than ritualistic, more a carnivalesque celebration of being alive than an attempt to cause physical harm. Images of marching crowds chanting "We are the Mods! We are the Mods!" call to mind a military parade and, as such, foreground the subculture's masculine image. Emphasizing the performative nature of the Brighton clashes, Rob Shields contends: "After the media hysteria, those smiles leave the different impression of a boisterous carnival of violence rather than planned attacks by groups of bitter criminal enemies, or the frustration of disenfranchised ethnic groups or the poor" (Shields 104). In the film, the carnivalesque scuffle between Mods, Rockers, and the riot police allows Jimmy to experience a double masculine fulfilment. On the one hand, his flirtatious relationship with Steph becomes carnal (they have sex in the back yard of a building), on the other hand, he is taken into custody with Ace Face, the legendary Mod leader.

In Brighton the protagonist comes to embrace an ideal self, the much desired image of the authentic Mod. This sense of being fully alive nevertheless quickly deteriorates upon returning home and trying to redefine his identity in the everyday environment: Jimmy gets sacked both from his parents' home and his job; furthermore, his erratic behavior alienates him from both Steph and fellow Mods. As Stephen Glynn asserts, "[t]he fulcrum of 
Quadrophenia is an analysis of someone trying to keep up with his subcultural peers and not succeeding. Jimmy fails in and is failed by the four key relationships in his life: his family, his job, the girl and the group — in short, a quadrophonic failing” (Glynn 82). What Jimmy really fails in is conformity to what Victor Turner defines as a status system, "a structured, differentiated, and often hierarchical system of politico-legal-economic positions with many types of evaluation, separating men in terms of 'more'or 'less"' (96). Set in opposition with the system is communitas, an inferior, marginal, and liminal form of human relations relying upon myth, symbols, ritual, works of art, and other cultural forms that "provide men with a set of templates or models which are, at one level, periodical reclassifications of reality and man's relationship to society, nature, and culture" (128-29). Turner's definition of communitas is remarkably close to how we understand subcultures, and how Quadrophenia portrays the spontaneous and immediate Mods in Brighton battling not only rockers but a status-bound social order.

The seaside also serves as the location of a rite of passage for Jimmy, who feels becoming part of the inner circle of this subcultural tribe after being offered cigarettes, and trialed together with his hero, Ace Face. Before experiencing the carnivalesque liminality of the Brighton riots, Jimmy lives through an episode of individual liminality on the seashore after being thrown out of a club for causing havoc. He spends the night wandering on the beach, and at daybreak his solitary figure dwarfed by the stormy ocean comes through as a sublime littoral image. His material inferiority to the liquid vastness offers a spatial expression to a person with inferiority complex. Jimmy is entrapped by anxieties of being unimportant, useless, and, underneath it all, just the same as everyone else. Resembling Pinky from Brighton Rock, he places individuality above community. His participation in the Mods' way of life is less a commitment to communitas then a means to convince others about his presumed superior being. In fact, he is uninterested in having fun for fun's sake and being just 
a lad; Jimmy thrives to become a "face", a Mod role model, a leader everyone recognizes. With reference to Turner, I claim that Jimmy is dedicated to the Mod ethos out of egotism; he would want to introduce the status system within the communitas, while his bitter attempts to prove that Mods are superior and more authentic actually say more about his own desire to be recognized.

Jimmy's littoral experience in Brighton is an awakening call, but the wrong type. Failing to address his inferiority crisis by forging social relations based on trust, he invests all his energy in forging a hegemonic masculine identity. Jimmy compensates for his disintegrating psychosocial relations with verbal and physical abuse, and becomes absorbed in paranoid and toxic masculinity. In a final act of both real and symbolic violence filmed on Beachy Head — on the top of the cliff face, the threshold between the land and the sea, the above and the below, life and death-Jimmy destroys the sacred Mod symbol, the scooter, and kills his attachments to the subculture. Nevertheless, it is unlikely that this entails giving up on the commitment to prove his superiority elsewhere. The cyclic structure of the film seems to suggest such a reading: the opening shot of Quadrophenia is not just a flashforward of the final scene, but also an allegory of the protagonist's endless quest for an illusionary ideal. This quest is symptomatic of the psychology of holiday seekers in general, and seaside tourists in specific. In fact, it is the dependence of escape on capture and capture on escape (after all, is not escape always a form of capture, and vice versa?) that guarantees the unbroken popularity of resorts.

\section{Bhaji on the Beach: Hybrid Blackpool}

If the Brighton of Brighton Rock and Quadrophenia is portrayed as a masculine stronghold, the Blackpool of Bhaji on the Beach is a feminized and Orientalized seaside resort. As Ana Cristina Mendes asserts, “[a]t Blackpool, the characters' multiply inscribed 
identities, at the intersection of ethnic and gendered lines, place them in a position where they are forced to reconcile conflicting aspects of the British and Indian spheres they inhabit" (327): one significant aspect being the feeling of being neglected at home. In spatializing domestic entrapment members of the British Asian diaspora experience on a daily basis, Blackpool cannot really serve as a carnivalesque escape from patriarchal households.

One of the first feature films to explore diasporic female subjectivity, Gurinder Chadha's narrative, features a communitas that is more fragmented than unified, one with significant differences with regard to cultural roots, family and community loyalties, sexuality, and personal autonomy. It is probably only Simi, the organizer of the trip who shows awareness towards the identity politics dimension of community building, by making the following combative, motivational speech before departure to Blackpool: "it is not often that we women get away from the patriarchal demands made on us in our daily lives, struggling between the double yoke of racism and sexism that we bear. This is your day. Have a female fun time." In the very manner, Simi invites her fellow women to reflect upon their lives (often at a crossroads). Chadha takes viewers on a cinematic journey to recognize women of the South East Asian diaspora as other than "essentialized representatives of native culture and tradition" (22).

Given the many conflicts the film's day-trippers carry with themselves, and the flexible framework of the community, I claim that Blackpool is a spatialization of negotiating notions of home, community, and homeland (as imaginary, communal space). Theorizing the complex signifier of the home, Anannya Bhattacharjee writes: "One definition is the (conventional) domestic sphere of the heterosexual and patriarchal family. A second definition is as an extended ethnic community separate and distinct from other ethnic communities ... The third reference of home for many immigrant communities is to their 
nations of origin" (313-14). The domestic, the diasporic, and the national layers of the home as points of reference create the hybrid image of Blackpool in the film.

With regard to the domestic sphere, Blackpool chiefly functions as a temporary space of the carnivalesque, a fun zone. This is most apparent in the case of Ladhu and Madhu, two teenagers looking forward to enjoying intimate moments with British boys. Their transgression, however, is secretive: the more adventurous Madhu puts on provocative clothes and wears make-up to create a sexy Blackpool-image, but as the day trip comes to a close, she reverts back to a conservative appearance. Such acts of cautious non-conformity occur in familiar places of resort towns - the fish and chip shop, attractions offered on the piers, benches for love birds, to name just a few. Of a more complex nature is the case of Ginder, a mother with a young son, who has left an abusive husband for good, and is literally fleeing him. In Blackpool she finds some breathing space, gets a beauty treatment, puts on elegant clothes, and at Manhattan's one of the Chippendales performers invites her for a daring dance. Blackpool treats her as a young and beautiful lady, someone who is free to make choices. Such liberty proves to be an illusion: her husband aggressively confronts Ginder in the pivotal scene of the film, where domestic violence is avoided only after some of the women intervene. The scene, shot on the seashore, under the massive structure of a pier, is a spatial allegory of the underside of glamorous Blackpool: it captures the return of the repressed, temporality covered up by the thrills offered by resort culture. But while the thick metal pillars serve as visual tropes of Ginder's entrapment, the solidarity of fellow women foreground a protective communitas.

At the center of Bhaji on the Beach is the second aspect of the home, the South East Asian diaspora, and its marginalized subjects: women. As with Ginder, the female communitas shows its power to nurture, yet it can also be resentful, as in the case of Hashida, a girl in her late teens who is pregnant with the child of her Afro-Caribbean boyfriend, Oliver. 
The generational fissures within this second notion of the home are articulated through the supportive and empathic attitude of Hashida's peers and the bitter comments of the elders. Owing to her combatant temper, well-illustrated by the instance when she tells off both her resentful Indian aunts and the racist waitress in the snack bar, she is willing to contest Oriental gender norms and embrace a hybrid identity. Also, resisting the vulgar pleasures of Blackpool, she visits a clinic to seek the opinion of the Western medical profession and later finds solitude at the Grundy Art Gallery hosting a Mervyn Peake retrospective exhibition. Through her narrative, Blackpool is spatialized as a town beyond ephemeral pleasures, a town embedded in another heritage of Britishness, embodied by Britain as a welfare state, and as home to high art. As Hashida reconciles with Oliver and decides to fulfill her parents' wish to become a doctor, but also commits to keeping the baby, she embarks on a courageous rite of passage. While such a passage would involve a certain detachment from the female communitas, it would also offer the diasporic space as a home to other cultures, including the British and the Afro-Caribbean.

The third aspect of the home, namely that of empowerment achieved through fantasies about the native homeland, is brought into view by the characters of Asha and Rekha. The latter, a socialite lady visitor from India, ecstatically exclaims, "Bombay" as she catches sight of a busy Blackpool street. After sunset when the famous Blackpool Illuminations come on, Blackpool is further hybridized, and truly resembles a cityscape from a Bollywood production. For Rekha, India is like the real Blackpool, it is a globalizing region with an outward-looking economy dependent on tourism. For the elder British-Asian women the native homeland resembles the Blackpool of imaginations, and empowering fantasies of escape. This is the case with Asha, whose reappearing nightmare visions of being subjected to the triple yoke of "Duty, Honor, Sacrifice" drives her into a Raj fantasy with Ambrose Waddington, a Kiplingesque gentleman with Occidental notions about Indian culture and 
endless complaints over the decline of British traditions. Asha feels at home in this fantasy, and her daydream transforms Blackpool into the Bollywood-like setting of ritual Indian courtship. Chadha does not belittle the transformative power of fantasy, as Asha will actually confront the patriarchy and stand up for Ginder in a manner she could never assume for defending herself in her nightmares.

\section{Last Resort: Post-Dreamland Margate}

In its most straightforward reading, Last Resort by Pawel Pawlikowski is about an Eastern European protagonist who, having her dreams of a better life in Britain shattered, returns home. Arriving from Russia to Britain with her ten-year-old son, Tanya is leaving behind the postcommunist nihilism that can offer only disillusionment to a sensitive soul like her, an illustrator of children's books. Tanya's real background story is not one connected to her British fiancé who never turns up at the airport; it is that of her having been betrayed by a homeland disintegrating into a post-empire nightmare of ruthless competitiveness. It is the determination to escape from this that turns Tanya into a refugee seeking political asylum at Stansted and results in her being transported to Margate (called Stonehaven in the film).

There is nothing haven-like in the Margate for the refugees; in fact, Tanya's son, Artyom calls it "the armpit of the universe," a setting, as Sandra Ponzanesi notes, "abstracted and stylised, empty of traffic and people, filmed in desaturated colours to enhance its visual bleakness" (Ponzanesi 679). Compared to a town well past its heyday as a popular seaside resort, as captured by Lindsay Anderson's free cinema documentary, O Dreamland (1965), it is fair to say that Pawlikowski's Margate, marked off from the outside world by barbed wire fence, patrol dogs, and surveillance cameras to track every move, boasting a closed railway station, is more cataclysmic than carnivalesque. People worn out by endless waiting, little social interaction, and occasional violence are mirrored in the post-apocalyptic imagery of 
abandoned beaches, empty streets, and run-down buildings. ${ }^{3}$ Local business owners quickly adapt to this atmosphere of destitution, like male protagonist Alfie, who probably makes more profit by selling telephone cards and tobacco to refugees than operating a games arcade and working as a bingo caller. Others adapt in more exploitative ways and recruit young refugee women for cyber prostitution. The post-Dreamland Margate no longer benefits from workingclass consumerism: it is spatialized as the underbelly Britain of limited career opportunities, that is, it "becomes the symbol of postcommunism in Britain, a Britain that in no way adheres to the Cold War mindset of a prosperous and affluent country with a secured place in history" (Kristensen 50). Besides marking the last days of a British seaside hospitality industry, the Margate of Last Resort also renders legible Enlightenment notions of hospitality being subordinated to immigration policies in the era of fortress Europe. ${ }^{4}$ If conditional stateprovided hospitality fails because it enforces a rigid legal regime and sets bureaucratic terms for those seeking asylum, the unconditional individual-provided hospitality of Alfie, his desire to be romantically involved with Tanya, falls back on master narratives of a phallogocentric epistemic regime, according to which the "damsel in distress" is saved by the handsome, compassionate hero.

Entangled in such hospitality pacts, Tanya's escape proves a dead end, a form of double yoke that would surely result in a hegemonic existence, a subjectivity without autonomy, a life overshadowed by a permanent sense of being dead. Her decision to flee Margate with the help of Alfie on a boat and to resist a life of compromise in Britain is empowering. As opposed to the other films analyzed here, the sea in Last Resort is not a barrier but an opening through the fluid space of which characters leave the land behind and allow new horizons to open. For Tanya a new beginning materializes in her profound determination to return home. Her words, "I have to go back and start my life" critical realization that her past attempts of escape have been self-deceptive and have only 
increased entrapment. If I had to choose a single image that captures Tanya's mind-frame, it would be the wall-size poster of a tropical seaside sunset in the Margate apartment they occupy; a fantasy-vision of a dreamland which has begun to peel off and revealed itself as an illusion. Similarly, the original idea of a normal family with a Western husband to take care of her and Artyom is gradually abandoned as she learns self-care. The weary poster forms a link between space and subjectivity: as a commentary on post-Dreamland Margate, it sums up the bleak outlooks for many British seaside resorts, while as a visual symbol of a corrupted fantasy it propels her to move on and create a post-Margate identity.

\section{Conclusions}

The common denominator of the films analyzed is their inclination to treat the real, physical location of seaside resorts (Brighton, Morecombe, Blackpool, Margate) as spatializations of their characters' social anxieties, strained communal belonging, and pursuit of independence. As such, the notions and visions protagonists cater about the space of the resort reveal complex mental cartographies and psychic mechanisms underlying the desire to escape, as well as the realization of being entrapped, feeling dead or, for that matter, alive. As suggested with regard to The Birthday Party, an unconventional resort film, cinema spatializes the seaside resort within the tug of war between the forces of capture, and those of release, a struggle richly illustrated by the chosen films belonging to different generic, stylistic and narrative traditions, while featuring a variety of characters and conflict types.

The films also demonstrate the inadequacy to seize the seaside experience through essentialist notions. Depending on one's age, gender, and class, furthermore, determined by whether a person is a local resident, a visitor, a citizen or a refugee, the resort will appear as a fluid space accentuating different aspects of entrapment and escape. Brighton Rock and The Entertainer feature locals and their native perceptions, while Quadrophenia and Bhaji on the 
Beach focus on holiday seekers, with Last Resort and The Birthday Party portraying both. Protagonists in the first group of films are dead inside: Pinky is morally corrupt and Archie lacks artistic talent. In the case of Archie and Alfie from Last Resort, the anxieties of local residents correlate with the economic decline and fading popularity of Morecombe and Margate, respectively. The second group features visitors, fugitives, and refugees, who desire to get away from the daily rat-race and unrewarding social positions. In these films escape is presented as a collective experience linking the psychological portrayal of the protagonists with inquiries into the psycho-socio dynamic of the Mod subculture and the patriarchal diaspora. Reversing traditional perceptions of the masculine North and the effeminate South, Blackpool is spatialized along the liminal fantasies of women fleeing their subordinate domestic positions, while Brighton serves as the stage for carnivalesque rituals of hegemonic masculinity. Yet, unlike the British Asian women who find empowerment in the liveliness of Blackpool, Brighton for Jimmy brings no release from anxieties and only prolongs his identity quest. In The Birthday Party and Last Resort, the entrapment of locals is uniform: Meg and Petey are lonely in their marriage that lacks affections and Alfie, eager for intimacy but living a life of solitude, hardly fares better. Yet, the films differ considerably in their representation of the protagonists' escape. For Stanley it concludes with infantilization, a reversed rite of passage, yet Tanya's rite of passage passes through the stages of visitor refugee and fugitive in Margate only to find closure as she awakes from deceptive ideals of a better life and returns to Russia.

The titles explored in this article could be labeled as art cinema. Maybe because of their appeal to an erudite audience, they subscribe to some of the biases writers, social commentators, and scholars have employed throughout the twentieth century in their criticism on popular culture and the seaside resort which they perceived as its most vulgar form. The rejection of collective rituals and the glorification of individuality, autonomy, and the pursuit 
of liberty as the persistent Enlightenment paradigm offers an ideological heritage that some of these films (Brighton Rock, The Entertainer) identify with. Voicing subtle criticism towards late capitalist consumerism, the stories explore the psychopathology behind our modern fascination with the celebrity image (The Entertainer, Quadrophenia), the endless pursuit of fantasies (Quadrophenia, Last Resort), but also the transformative potential behind these (Bhaji on the Beach, Last Resort). The seaside resort is likely to remain an inspiration for future filmmakers, a mirror of British identity in the making and remaking, and a commentary on the obligatory human experience of losing and finding ourselves.

University of Debrecen

\section{Acknowledgments}

This research was supported by the János Bolyai Scholarship of the Hungarian Academy of Sciences, and the ÚNKP-20-5 New National Excellence Program of the Ministry of Human Capacities.

\section{Notes}

1 Hays Code, or the Motion Picture Production Code, set moral guidelines for Hollywood, and required studios to self-censor any content that would present violations of the law in a sympathetic manner.

Commenting on the attention-seeking attitude of Mods, Stephen Glynn emphasizes that “to 1960s Mod purists, not only was Quadrophenia's portrayal hopelessly inaccurate, but it also encouraged gangs of raucous wannabes" (Glynn 80-81).

${ }^{3}$ Without a distinct starting and end point, the story lacks closure; its Moebius strip structure is carried by the image of the scorching sun in the first shot of the film (and the 
conclusion of the story), juxtaposed by the headlight of a scooter in the next shot: the chronological beginning of the story.

${ }^{4}$ Bearing in mind that the entrance to the Dreamland Amusement Park is actually an Art Deco cinema building, Pawlikowski seems to suggest that the town itself became an authentic location for a post-apocalyptic story.

${ }^{5}$ In an illuminating account of the shift in the official script underlying immigration policies, Katarzyna Murawska-Muthesius claims that "[t]he end of the Cold War altered radically the former pact of hospitality applicable to Eastern European newcomers, stripping it from its blunt ideological priorities, and adopting the 'standard' policy of highly restricted admittance, which positions the issue of economic self-sufficiency in the centre of border interrogation, no different from that offered to any non-refugee foreigner from non-western countries" (n.pag.).

${ }^{6}$ According to jan jagodzinski, Tanya's stay in Margate is tantamount to a slow emotional death, adding that her departure for a future, even if it is an unknown future outside the sphere of the familiar, "is a way to start up the cycle of time and life once again, to get back a rhythm that has been flatlined. (114)

\section{Works Cited}

Banerjee, Bidisha. “Traveling Bodies: Gender, Nationalism and Diasporic Identity Formation in Gurinder Chadha's Bhaji on the Beach.” Asian Cinema 20.2 (Sept. 2009): 18-38. Print.

Bhattacharjee, Anannya. “The Public/Private Mirage: Mapping Homesand Undomesticating Violence Work in the South Asian Immigrant Community." Feminist Genealogies, Colonial Legacies and Democratic Futures. Ed. M. Jacqui Alexander and Chandra Talpade Mohanty. New York: Routledge, 1995. 308-29. Print. 
Cohn, Ruby. "The World of Harold Pinter." The Tulane Drama Review 6.3 (1962): 55-68. Print.

Cross, Garry C., and John K Walton. The Playful Crowd. Pleasure Places in the Twentieth Century. New York: Columbia UP, 2005. Print.

Cross, Gary C. Worktowners at Blackpool: Mass-Observation and Popular Leisure in the 1930s. London: Routledge, 1990. Print.

Fiegel, Lara. "Kiss Me Quick: The Aesthetics of Excess in 1930s Literature and Film." Modernism on Sea: Art and Culture at the British Seaside. Ed. Lara Feigel and Alexandra Harris. Peter Lang, 2009. 15-34. Print.

Glynn, Stephen. "Mod at the Movies: 'Face' and 'Ticket' Representations of a British Subculture." Youth Subcultures in Fiction, Film and Other Media. Ed. Nick Bentley, Beth Johnson and Andrzej Zieleniec. London: Palgrave, 2018. 75-90. Print.

Greene, Graham. Brighton Rock. London: Heinemann and Bodley Head, 1970. Print.

Hebdige, Dick. Subculture. The Meaning of Style. London: Routledge, 2002. Print. jagodzinski, jan. Schizoanalytic Ventures at the End of the World. Film, Video, Art, and Pedagogical Challenges. Cham: Springer-Palgrave, 2019. Print.

Kerry, Matthew. The Holiday and British Film. Basingstoke: Palgrave, 2012. Print.

Kristensen, Lars. "Mapping Pawel Pawlikowski and Last Resort." Studies in Eastern European Cinema 3.1 (2012): 41-52. Print.

Mendes, Ana Cristina. Triangulating Birmingham, Blackpool, Bombay: Gurinder Chadha's Bhaji on the Beach. Revista Anglo Saxonica. Ser. III no. 1 (2010): 327-40. Print.

Morgan, Nigel. J. and Annette Pritchard. Power and Politics at the Seaside: The Development of Devon's Resorts in the Twentieth Century. U of Exeter P, 1999. Print. 
Murawska-Muthesius, Katarzyna. "The Last Resort of an Eastern European 'Refugee by Mistake': On diasporic cinema." ArtMargins: Contemporary Central and Eastern Europen Visual Culture. 20 Dec. 2003. Web. 2 Nov. 2020.

Osborn, John. The Entertainer. London: Faber, 1961. Print.

Pinter, Harold. The Birthday Party. London: Faber, 1991. Print.

Ponzanesi, Sandra. “The Non-Places of Migrant Cinema in Europe”. Third Text 26:6 (2012): 675-90. Print.

Richardson, Tony. The Long-Distance Runner: An Autobiography. New York: William Morrow and Co., 1993. Print.

Shields, Rob. Places on the Margins. Alternative Geographies of Modernity. London: Routledge, 1991. Print.

Thomas, Colin. “'The Birthday Party.' The Georgia Straight”. May 25, 2006. 11, 22. Web. 13 Oct. 2020.

Tibbets John C. "Breaking the Proscenium: Tony Richardson, the Free Cinema, the Royal Court, and Wood/all Films (Look Back in Anger [1959] and The Entertainer [1960]." The Cinema of Tony Richardson: Essays and Interviews. Ed. James M. Welsh and John C. Tibbetts Albany: State U of New York P, 1999. Print.

Turner, Victor. The Ritual Process: Structure and Anti-Structure. Chicago: Aldine Publishing, 1969. Print.

Warshow, Robert. "The Gangster as Tragic Hero." The Immediate Experience: Movies, Comics, Theatre and Other Aspects of Popular Culture. Garden City: Doubleday, 1962. 127-33. Print. 